\title{
Weed suppression by twelve ornamental ground cover species
}

\author{
C.L. Foo, K.C. Harrington, and M.B. MacKay \\ Institute of Natural Resources, Massey University, Private Bag 11-222, Palmerston North \\ 4442, New Zealand \\ Corresponding author: K.Harrington@massey.ac.nz
}

\begin{abstract}
Twelve ornamental ground cover species were planted then monitored for 2 years to assess their relative usefulness for controlling weeds. Persicaria capitatum established quickly and covered the plots, but it was unsuitable for keeping weeds controlled because it died back each winter from frost damage. Acaena inermis and Muehlenbeckia axillaris also completely covered the plots within 12 months, and they effectively prevented weeds from establishing during a 5-month assessment period in the second year. Many of the other planted species also suppressed weeds well, and those that decreased the ratio of red to far red light intercepted by the soil underneath them best gave better weed control. Other ground covers that suppressed weeds well included Ajuga reptans, Coprosma acerosa, Grevillea lanigera, Juniperus procumbens, Pimelea prostrata, Sedum mexicanum and Veronica peduncularis. Some species, such as $S$. mexicanum and $P$. prostrata, shaded the soil less well at certain times each year.
\end{abstract}

Keywords ground cover plants, competition, weed control.

\section{INTRODUCTION}

Ornamental ground cover plants can be an effective weed deterrent when fully grown, as their dense foliage prevents new weed seedlings from establishing (Thomas 1977). They can help reduce the labour requirement for weeding of planted sites, and also reduce the use of herbicides needed for weed control (van der Spuy 1976). Grounds managers may decide on the most suitable species based on the composite criteria of aesthetics, cost, availability, and rates of growth and establishment. Before suppression of weeds can take place, ground cover species need to become sufficiently established to provide dense shading of the soil. Various methods may be employed to help with this establishment, such as use of mulch materials, hand weeding or selective herbicides (Foo et al. 2010a). For some ground cover species, information may be available on suitable selective herbicides to use (Foo et al. 2010b). However, once established, ground cover species can vary quite considerably in their ability to keep weeds from establishing.

The objective of this work was to compare a range of ground cover species with different growth forms for their effectiveness at preventing weeds from establishing, and to see if this could be explained by the extent to which they block light.

\section{MATERIALS AND METHODS}

Twelve ground cover plant species of different growth habits were selected for this study. 
They were: Acaena inermis 'Purpurea', Ajuga reptans 'Caitlin's Giant', Coprosma acerosa 'Taiko', Grevillea lanigera 'Little Drummer Boy', Juniperus procumbens 'Nana', Lithodora diffusum 'Grace Ward', Muehlenbeckia axillaris, Ophiopogon planiscapus, Persicaria capitatum (syn. Polygonum capitatum), Pimelea prostrata 'Anatoki', Sedum mexicanum 'Acapulco Gold' and Veronica peduncularis 'Oxford Blue'. The species differed from each other in size of leaves, plant height, extent of rooting along nodes and clumpiness of growth.

At a site near Palmerston North, an area of Manawatu fine sandy loam soil was cultivated. The species were planted in December 2008 into $4.0 \mathrm{~m}^{2}$ plots, with three plants per plot planted at $1.0 \mathrm{~m}$ spacings within the plots in a triangular pattern. Each species was planted into three different plots (replicates) within a randomised block design. After planting, sawdust mulch was applied 6-7 $\mathrm{cm}$ deep following an application of ammonium sulphate ( $200 \mathrm{~kg} \mathrm{~N} / \mathrm{ha})$. During the establishment phase, any weeds were removed by hand. Measurements of plant diameter and height were made every 2 months.

By May 2010, the plants were considered to be established. Weeds were beginning to appear more regularly due to thinning of the sawdust mulch and from wind-blown seed. From 17 May to 23 Oct 2010, no weeding was done to determine how well the ground covers could prevent weeds from establishing. At the end of this period, weeds were harvested from each plot, with weeds growing in parts of the plot not covered by the ground cover species separated from weeds within ground cover canopies. The weeds were dried at $80^{\circ} \mathrm{C}$ and weighed.

The light intensity reaching the soil under each ground cover plant was measured on 15 June and 1 November 2010 using Li-Cor light sensors attached to a LI-1000 data logger. Measurements of red light at $660 \mathrm{~nm}$, far-red light at $730 \mathrm{~nm}$ and total light between 400-700 nm under each plant were compared with intensity beside the plants. The red and far-red wavelengths coincide with phytochrome sensitivity (Kendrick \& Frankland 1983).
An analysis of variance was performed on all data using SAS 9.2. Each set of data was checked for normality and appropriate transformations were used (common logarithm $\left(\log _{10}\right)$ or square root transformation) where necessary prior to the ANOVA to improve normality (Smith 1976). A paired t-test checked whether differences between June and November in red to far-red light ratios and light interception were significant. The relationship between weed mass and light measurements was investigated by calculating Pearson's correlation coefficients.

\section{RESULTS}

The species varied in size when planted (Table 1 ), although this had little effect on rate of establishment. Within 2 months of planting, the P. capitatum plants were over four times their original diameter. After 1 year, the diameter of P. capitatum, A. inermis and M. axillaris plants had exceeded $200 \mathrm{~cm}$ (Table 1). This meant they had merged into one another within the plots making it impossible to measure individual plant diameter. Thus these species were removed from the analysis of variance of the means. Conversely, some species were slow to expand, with O. planiscapus only doubling its original diameter after 2 years.

For some species such as A. inermis and M. axillaris, estimates of how well the ground in each plot was covered by the plants related directly to the diameter of each plant (Table 2), with the soil being almost totally covered from May 2010 (18 months after establishment) onwards for these two species. However, for the most rapidly establishing species, $P$. capitatum, although the soil was $80 \%$ covered at 2 months after planting, it failed to maintain a good cover of the soil throughout the year, dying back over winter due to frost damage. Lithodora diffusum was the other species that failed to maintain a dense cover of the soil throughout the duration of the trial, with a number of the plants apparently succumbing to disease and dying. Most species had covered at least $60-70 \%$ of the soil after 22 months, although $O$. planiscapus never covered more than $30 \%$ of the soil (Table 2 ). 
Table 1 The mean diameter $(\mathrm{cm})$ of the planted ground cover plants at time of establishment (December 2008), and 2 (February 2009), 12 (December 2009) and 22 months (October 2010) after planting. Means within a column sharing the same letter are not significantly different at $\mathrm{P}>0.05$.

\begin{tabular}{lrlrlrrrrr}
\hline Species & \multicolumn{2}{c}{ Dec 08} & \multicolumn{2}{c}{ Feb 09} & \multicolumn{2}{c}{ Dec 09} & \multicolumn{2}{c}{ Oct 10} \\
\hline A. inermis & 16.5 & $\mathrm{~d}$ & 52.5 & $\mathrm{efg}$ & $>200$ & & $>200$ & \\
A. reptans & 32.5 & $\mathrm{~b}$ & 82.7 & $\mathrm{~b}$ & 103.6 & $\mathrm{a}$ & 161.8 & $\mathrm{a}$ \\
C. acerosa & 33.9 & $\mathrm{~b}$ & 57.9 & $\mathrm{def}$ & 80.5 & $\mathrm{bc}$ & 140.9 & $\mathrm{ab}$ \\
G. lanigera & 31.2 & $\mathrm{~b}$ & 70.9 & $\mathrm{c}$ & 88.2 & $\mathrm{abc}$ & 133.8 & $\mathrm{~b}$ \\
J. procumbens & 42.9 & $\mathrm{a}$ & 64.8 & $\mathrm{~cd}$ & 82.1 & $\mathrm{bc}$ & 127.7 & $\mathrm{~b}$ \\
L. diffusum & 23.1 & $\mathrm{c}$ & 41.2 & $\mathrm{~h}$ & 62.2 & $\mathrm{~d}$ & 85.9 & $\mathrm{c}$ \\
M. axillaris & 14.7 & $\mathrm{~d}$ & 46.5 & $\mathrm{gh}$ & $>200$ & & $>200$ & \\
O. planiscapus & 26.0 & $\mathrm{c}$ & 41.9 & $\mathrm{~h}$ & 55.6 & $\mathrm{~d}$ & 51.6 & $\mathrm{~d}$ \\
P. capitatum & 25.6 & $\mathrm{c}$ & 119.6 & $\mathrm{a}$ & $>200$ & & $>200$ & \\
P. prostrata & 22.4 & $\mathrm{c}$ & 50.7 & $\mathrm{fg}$ & 74.8 & $\mathrm{c}$ & 135.1 & $\mathrm{~b}$ \\
S. mexicanum & 8.4 & $\mathrm{e}$ & 28.9 & $\mathrm{i}$ & 59.3 & $\mathrm{~d}$ & 98.6 & $\mathrm{c}$ \\
V. peduncularis & 25.0 & $\mathrm{c}$ & 59.5 & $\mathrm{de}$ & 93.9 & $\mathrm{ab}$ & 120.1 & $\mathrm{~b}$ \\
\hline
\end{tabular}

Table 2 The mean percentage of the plot estimated to be covered by ground cover species at 2 (February 2009), 4 (April 2009), 12 (December 2009), 18 (May 2010) and 22 months (October 2010) after planting. Means within a column sharing the same letter are not significantly different at $\mathrm{P}>0.05$.

\begin{tabular}{|c|c|c|c|c|c|c|c|c|c|c|}
\hline Species & \multicolumn{2}{|c|}{ Feb 09} & \multicolumn{2}{|c|}{ Apr 09} & \multicolumn{2}{|c|}{ Dec 09} & \multicolumn{2}{|c|}{ May 10} & \multicolumn{2}{|c|}{ Oct 10} \\
\hline A. inermis & 35.0 & c & 56.5 & $\mathrm{~b}$ & 95.0 & $\mathrm{a}$ & 100.0 & $\mathrm{a}$ & 100.0 & $\mathrm{a}$ \\
\hline A. reptans & 46.4 & $\mathrm{~b}$ & 51.3 & $\mathrm{bc}$ & 78.3 & $\mathrm{~b}$ & 76.7 & $\mathrm{~b}$ & 85.0 & $\mathrm{~b}$ \\
\hline C. acerosa & 26.2 & d & 24.7 & $\mathrm{e}$ & 58.3 & $\mathrm{~cd}$ & 76.7 & $\mathrm{~b}$ & 76.7 & bc \\
\hline G. lanigera & 33.2 & c & 43.8 & c & 56.7 & $\mathrm{~cd}$ & 70.0 & c & 58.3 & e \\
\hline J. procumbens & 24.7 & d & 22.9 & ef & 35.0 & e & 66.7 & $\mathrm{~cd}$ & 71.7 & $\mathrm{~cd}$ \\
\hline L. diffusum & 22.9 & de & 20.6 & ef & 36.7 & e & 65.0 & cde & 42.5 & $\mathrm{f}$ \\
\hline M. axillaris & 26.6 & $\mathrm{~d}$ & 32.7 & $\mathrm{~d}$ & 88.3 & $\mathrm{ab}$ & 99.7 & $\mathrm{a}$ & 98.3 & a \\
\hline O. planiscapus & 18.2 & $\mathrm{f}$ & 19.6 & $\mathrm{f}$ & 30.0 & e & 25.0 & g & 21.7 & g \\
\hline P. capitatum & 80.0 & $\mathrm{a}$ & 89.9 & a & 13.3 & $\mathrm{f}$ & 53.3 & $\mathrm{f}$ & 45.0 & $\mathrm{f}$ \\
\hline P. prostrata & 34.8 & c & 34.8 & d & 51.7 & d & 63.3 & de & 63.3 & de \\
\hline S. mexicanum & 19.6 & ef & 19.6 & $\mathrm{f}$ & 50.0 & d & 50.0 & $\mathrm{f}$ & 67.5 & cde \\
\hline V. peduncularis & 34.8 & $\mathrm{c}$ & 43.3 & c & 65.0 & c & 60.0 & $\mathrm{e}$ & 73.3 & $\mathrm{~cd}$ \\
\hline
\end{tabular}

For some species, there was little change in height between 2 months and 2 years after planting, with some species, such as A. inermis and $A$. reptans, actually decreasing in height as they formed more of a prostrate cover over time (Table 3). Some of the larger species, such as $G$. lanigera and C. acerosa, did increase in height as the plants developed to their full size, and likewise the lowest of the species initially (S. mexicanum) doubled in height as it became a more compact, clump-like plant over time.

Most ground cover plants had very few weeds develop within their canopies between May and October 2010, with S. mexicanum, M. axillaris, A. inermis, C. acerosa and A. reptans being particularly resilient to weed establishment (Table 3 ). The height of the ground covers generally had little influence on their ability to stop weeds from 
establishing, and this was more influenced by the ability of the ground cover species to form dense swards. The frost damage to P. capitatum made it vulnerable to weed ingress. The quantity of weeds found within the total plot was mainly a reflection of how well the species had covered the plots by this time, with M. axillaris, A. inermis and $C$. acerosa having particularly weed-free plots (Table 3 ).

Almost all of the ground cover plants reduced the average light intensity at the soil beneath their canopies to below $10 \%$ of full light intensity, and the species with the least weeds emerging from them often were not the species that had blocked the most light. The P. capitatum plants let through the most light due to being damaged by frost. Although the O. planiscapus plants did not have significantly more light penetration than other species with few weeds, the high weed mass within these plots occurred because of an infestation of the perennial weed Oxalis corniculata that probably existed within the original pots planted and was never successfully removed prior to May 2010.

The ratio of red to far red light above the ground cover plants was on average 1.6. Shading by the ground covers substantially decreased the amount of red light compared with far-red light reaching the soil beneath the ground cover plants (Table 4). The species with the lowest weed mass present within them generally had a ratio of red to far-red light less than 0.4 . The $S$. mexicanum had a very low ratio in June but this had increased significantly by November when it had begun flowering, at which time the plant became less tightly clustered. The $P$. capitatum plants were blocking red light to a greater extent in November compared with June as the dead frosted leaves in June had been replaced by healthy regrowing leaves in November.

A significant $(\mathrm{P}<0.05)$ Pearson correlation coefficient of 0.44 suggested there was a relationship between the ratio of red to far-red light measured under ground cover plants in June 2010 and the weed mass subsequently found growing within these ground covers in October 2010. There was no significant correlation between weed mass and red to far red light ratios measured in November 2010, nor between weed mass and light penetration figures measured in either June or November.

Table 3 The mean height (cm) of ground cover plants at 2 months (February 2009) and 22 months (October 2010) after being planted in December 2008, and also the total weed mass (g dry matter $/ \mathrm{m}^{2}$ ) in October 2010, both from the area covered by the ground cover species and also from the entire plot. Means within a column sharing the same letter are not significantly different at $\mathrm{P}>0.05$.

\begin{tabular}{|c|c|c|c|c|c|c|c|c|}
\hline \multirow{3}{*}{$\frac{\text { Species }}{\text { A. inermis }}$} & \multicolumn{4}{|c|}{ Mean height } & \multicolumn{4}{|c|}{ Total weed mass } \\
\hline & \multicolumn{2}{|c|}{ Feb 09} & \multicolumn{2}{|c|}{ Oct 10} & \multicolumn{2}{|c|}{ inside canopy } & \multicolumn{2}{|c|}{ within whole plot } \\
\hline & 11.5 & cde & 7.1 & $\mathrm{f}$ & 0.009 & $\mathrm{~cd}$ & 1.6 & de \\
\hline A. reptans & 23.1 & $\mathrm{a}$ & 11.5 & de & 0.1 & $\mathrm{~cd}$ & 4.8 & bcde \\
\hline C. acerosa & 11.8 & $\mathrm{~cd}$ & 28.4 & $\mathrm{a}$ & 0.014 & $\mathrm{~cd}$ & 2.7 & cde \\
\hline G. lanigera & 17.6 & $\mathrm{~b}$ & 27.0 & $\mathrm{a}$ & 0.8 & bcd & 10.0 & abcde \\
\hline J. procumbens & 10.6 & de & 16.3 & $\mathrm{bc}$ & 1.9 & bcd & 17.7 & abcd \\
\hline L. diffusum & 11.1 & de & 18.2 & $\mathrm{~b}$ & 3.12 & $\mathrm{bc}$ & 89.1 & $\mathrm{a}$ \\
\hline M. axillaris & 9.5 & ef & 12.6 & de & 0.006 & $\mathrm{~cd}$ & 0.02 & $\mathrm{e}$ \\
\hline O. planiscapus & 13.8 & $c$ & 12.4 & de & 43.1 & $\mathrm{a}$ & 61.3 & $\mathrm{ab}$ \\
\hline P. capitatum & 10.0 & def & 10.1 & e & 5.8 & $\mathrm{~b}$ & 43.6 & $\mathrm{abc}$ \\
\hline P. prostrata & 10.8 & de & 13.8 & $\mathrm{~cd}$ & 1.0 & bcd & 4.6 & bcde \\
\hline S. mexicanum & 8.3 & $\mathrm{f}$ & 18.0 & $\mathrm{~b}$ & 0.0 & $\mathrm{~d}$ & 33.0 & abcd \\
\hline V. peduncularis & 12.0 & $\mathrm{~cd}$ & 20.5 & $\mathrm{~b}$ & 1.3 & bcd & 125.8 & $\mathrm{a}$ \\
\hline
\end{tabular}


Table 4 The mean ratio of red to far-red light measured under the ground cover plants in June and November 2010, and the mean percentage of light intensity measured under the ground covers compared with above them. Means within a column sharing the same letter are not significantly different at $\mathrm{P}>0.05$. November values with asterisks were significantly different $(\mathrm{P}<0.05)$ from June values for the same species.

\begin{tabular}{|c|c|c|c|c|c|c|c|c|}
\hline \multirow{3}{*}{$\frac{\text { Species }}{\text { A. inermis }}$} & \multicolumn{4}{|c|}{$\begin{array}{l}\text { Red to far-red light ratio under } \\
\text { ground cover }\end{array}$} & \multicolumn{4}{|c|}{ Light penetration $(\%)$} \\
\hline & \multicolumn{2}{|c|}{ June 10} & \multicolumn{2}{|c|}{ Nov 10} & \multicolumn{2}{|c|}{ June 10} & \multicolumn{2}{|c|}{ Nov 10} \\
\hline & 0.49 & de & $0.35^{\star}$ & ef & 9.4 & bcd & $3.3^{*}$ & cdef \\
\hline A. reptans & 0.24 & $\mathrm{f}$ & 0.31 & ef & 10.2 & $\mathrm{bc}$ & 7.1 & bcd \\
\hline C. acerosa & 0.29 & $\mathrm{f}$ & 0.36 & ef & 3.4 & cde & 2.9 & def \\
\hline G. lanigera & 0.60 & $\mathrm{~cd}$ & $0.94^{*}$ & $\mathrm{a}$ & 3.2 & de & 6.5 & bcde \\
\hline J. procumbens & 0.34 & ef & 0.29 & ef & 1.7 & $\mathrm{e}$ & 1.0 & $\mathrm{f}$ \\
\hline L. diffusum & 0.88 & $\mathrm{~b}$ & 0.81 & $\mathrm{~b}$ & 3.9 & cde & 1.0 & $\mathrm{f}$ \\
\hline M. axillaris & 0.48 & de & 0.27 & $f$ & 18.0 & $\mathrm{a}$ & $2.1^{\star}$ & ef \\
\hline O. planiscapus & 0.38 & ef & 0.42 & $\mathrm{e}$ & 8.7 & bcd & 10.2 & $\mathrm{ab}$ \\
\hline P. capitatum & 1.08 & $\mathrm{a}$ & $0.61^{\star}$ & $\mathrm{cd}$ & 17.9 & $\mathrm{a}$ & 15.0 & $\mathrm{a}$ \\
\hline P. prostrata & 0.70 & c & $0.62^{*}$ & $\mathrm{~cd}$ & 6.6 & bcde & 7.8 & $\mathrm{bc}$ \\
\hline S. mexicanum & 0.28 & $\mathrm{f}$ & $0.73^{\star}$ & $\mathrm{bc}$ & 6.6 & bcde & 6.4 & bcde \\
\hline V. peduncularis & 0.49 & de & 0.57 & $\mathrm{~d}$ & 12.9 & $\mathrm{ab}$ & 7.6 & bcd \\
\hline
\end{tabular}

\section{DISCUSSION}

The results showed that the species selected for this trial varied substantially in rate of expansion and ability to keep weeds from establishing. A planting density equivalent to 1.0 metre between each plant was used, which made those plants that are smaller in size and slower to expand appear less useful as ground covers. The diameters of plants presented in Table 1 allow more appropriate planting spacings to be calculated if a more rapid cover of the soil by each species is required.

The number of weeds that established between May and October 2010 was not large. Although the sawdust was becoming thinner, it appears probable that most of the weeds that did establish had blown on to the plots, because the main species present have wind-blown seeds (e.g. prickly sow thistle (Sonchus asper), dandelion (Taraxacum offinale), broad-leaved fleabane (Conyza sumatrensis), groundsel (Senecio vulgaris)). Yorkshire fog (Holcus lanatus) was another major species present, and seed would have blown on to plots from an area nearby.
The significant correlation coefficient suggested the ratio of red to far-red light in June gave a better indication of which species were suppressing weeds well in the period from May to October than the decrease in light penetration. With L. diffusum, a lot of necrotic leaf material was present, so light was still being suppressed overall, but the ratio of red to far-red light was higher in these treatments, which probably explains why weeds managed to establish in these plants more successfully than other species. The low red to far-red light ratio presumably kept weed seeds with phytochrome dormant (Kendrick \& Frankland 1983).

Persicaria capitatum was the fastest establishing ground cover and formed dense swards over summer. It appeared to perform badly in the present trials because of its susceptibility to frost. But in warmer parts of the country it may be the best of the species assessed, although its prolific seeding and rampant growth may result in this becoming a weed itself in such environments.

Other species that covered the ground rapidly but remained dense throughout the year and 
gave good weed control, included A. inermis and $M$. axillaris. Although $S$. mexicanum formed very dense covers at some times of the year, its tendency to become more open in its growth habit while flowering in spring may allow weeds to establish during summer, and also its brittle nature made it quite susceptible to damage from animals such as rabbits. Some of the more woody species in the trial such as $C$. acerosa and J. procumbens were slower to spread, but formed dense covers once established and appeared very suitable for suppressing weeds at this stage. Lithodora diffusum and V. peduncularis seemed susceptible to disease under the growing conditions within the present trial. The O. planiscapus plants never expanded in size very much during the 2 years of assessment, but might be more aggressive under different environments or once established for a longer period of time. The G. lanigera and $P$. prostrata plants both formed dense covers that kept weeds under control, with G. lanigera being one of the tallest species assessed. Pimelea prostrata showed a tendency to become less dense each year in late summer.

\section{ACKNOWLEDGEMENTS}

Funding by the Massey University Doctoral Scholarship, the Dan Watkins Scholarship and the Sir Victor Davis Foundation is gratefully acknowledged. We also thank the field technicians from the Institute of Natural Resources for their assistance.

\section{REFERENCES}

Foo CL, Harrington KC, MacKay MB 2010a. Comparison of weed control techniques to establish three ground cover species. New Zealand Plant Protection 63: 96-101.

Foo CL, Harrington KC, MacKay MB 2010b. Herbicide tolerance of three ornamental ground cover species: Polygonum capitatum, Sedum mexicanum and Soleirolia soleirolii. New Zealand Plant Protection 63: 303-306.

Kendrick RE, Frankland B 1983. Phytochrome and Plant Growth. Edward Arnold, London. $76 \mathrm{p}$.

Smith JEK 1976. Data transformations in analysis of variance. Journal of Verbal Learning and Verbal Behavior 15: 339-346.

Thomas GS 1977. Plants for ground cover (revised). Aldine Press, London. 282 p.

van der Spuy U 1976. Gardening with Groundcovers.A.H.\&A.W.Reed, Wellington. $112 \mathrm{p}$. 